\title{
Chapter 6 \\ Is Spain Becoming a Country of Emigration Again? Data Evidence and Public Responses
}

\author{
Anastasia Bermudez and Elisa Brey
}

\subsection{Introduction}

The global financial and economic crisis that erupted at the end of 2007 has had a dramatic impact in the Southern EU member states, including Spain. Some of these countries despite having a history of emigration had lately become major attraction poles for immigrants as their economies expanded and demanded new workers. However, as the crisis deepened, labour markets contracted severely with two consequences: growing unemployment and increased emigration (as well as reduced immigration). Being such a recent phenomenon, there is still a lack of detailed knowledge about these outflows, something that has contributed to polarize opinions on the causes and consequences.

In the case of Spain, some public discourses portray this new emigration as limited and the result mainly of immigrants returning to their countries of origin (or re-emigrating) as labour opportunities decrease. Since one of the main focuses of migration policy post-crisis has been return migration, this could be perceived as positive. Equally, the emigration of young, qualified natives is seen as mostly the choice of individuals in search of new experiences or as part of a globalising labour force, rather than as a negative result of the crisis. By contrast, others point out that official data underrepresents the true extent of current emigration and its main characteristics. As well as arguing that the outflows are larger than assumed and the outcome of poor job opportunities and reduced social expenditure, critics point out

\author{
A. Bermudez ( $\triangle)$ \\ Department of Social Anthropology, Universidad de Sevilla, Sevilla, Spain \\ CEDEM, Université de Liège, Liège, Belgium \\ e-mail: abermudez1@us.es \\ E. Brey \\ CEDEM, Université de Liège, Liège, Belgium
}

GEMI, Universidad Complutense de Madrid, Madrid, Spain 
that emigration is especially affecting the young and highly educated, which could have serious economic and demographic effects.

The following sections delve further into these questions, with the aims of clarifying what the available statistics say about recent emigration from Spain and of analysing the policy and public responses. To contextualize the current situation, we start with a description of key economic and migration data and then look into main destinations and the sociodemographics of recent outflows, to finish with a critical appraisal of policies and public debates.

\subsection{The Relationship Between Economics and Migration: The Impact of the Crisis}

From the mid-1990s, Spain enjoyed a period of strong and sustained economic growth reflected in the expansion of its labour market. Employment rates climbed gradually to reach a peak of $69.5 \%$ in 2007, just below the EU-28 average. At the same time, and despite the enlargement of the workforce (Alonso Pérez and Furio Blasco 2010), unemployment declined to an all-time low of $8.2 \%$, slightly above the EU value (Labour Force Survey, LFS, Eurostat). However, the present crisis put an end to this bonanza in a much more dramatic way than the recessions of the mid1970s and early 1990s, both in terms of economic deceleration and job losses (Ortega and Peñalosa 2012).

Although the crisis has affected labour markets globally, the impact in Spain has proven how unstable the previous period of prosperity was. After GDP growth rates of around $4 \%$ the previous 3 years, since the crisis started the economy has contracted (by $-3.6 \%$ in 2009) or barely grown (by $1.4 \%$ in 2014). As a result, annual employment rates have fallen to the levels registered at the beginning of the twentyfirst century, while unemployment reached $24.5 \%$ in 2014 (more than 14 percentage points above the EU average). In addition, over $29 \%$ of the population in Spain is considered to be at risk of poverty or social exclusion (up from $23 \%$ in 2007), while income inequality has augmented. The impact of all this has been uneven. Male unemployment rates more than tripled from 2007 to 2014, although women continue to record a slightly higher figure (Eurostat data). But it seems to be young people who have seen their chances of entering or remaining in the job market most affected (OPAM 2012). By 2014, among the group 16-19 years old, over two-thirds of the economically active were unemployed, while more than half of those aged 20-24 were in the same situation (see Table 6.1). Although younger people have traditionally been more exposed to joblessness, the impact of the current crisis has generated concerns about the loss of human capital due to inactivity or emigration (González Enríquez and Martínez Romera 2014; Navarrete Moreno 2013).

Educational attainment also influences labour market opportunities, with unemployment hitting hardest those with the lowest levels of formal education. Still, at the end of $2014,14.3 \%$ of people with higher education could not find a job. The 
Table 6.1 Annual unemployment rates (\%) by age group in Spain, 2007-2014

\begin{tabular}{l|r|r|l|l|l|l|l|l}
\hline & 2007 & 2008 & 2009 & 2010 & 2011 & 2012 & 2013 & 2014 \\
\hline $16-19$ & 28.7 & 39.4 & 55.2 & 61.3 & 64.0 & 72.6 & 74.0 & 68.6 \\
\hline $20-24$ & 15.0 & 20.2 & 33.3 & 36.9 & 42.3 & 48.9 & 51.8 & 50.3 \\
\hline $25-29$ & 9.0 & 13.3 & 21.7 & 24.7 & 26.3 & 31.5 & 33.3 & 30.3 \\
\hline $30-44$ & 7.0 & 9.9 & 16.2 & 18.2 & 19.7 & 22.7 & 23.7 & 22.0 \\
\hline $45-54$ & 6.3 & 8.4 & 13.4 & 15.3 & 17.1 & 20.5 & 22.2 & 21.2 \\
\hline 55 and more & 5.7 & 7.1 & 11.5 & 13.5 & 14.4 & 17.3 & 19.4 & 19.3 \\
\hline
\end{tabular}

Source: Encuesta de Población Activa (EPA), Instituto Nacional de Estadística (INE)

data also shows that migrants have been particularly affected. The unemployment rate for the foreign born in 2014 was $33.3 \%$, more than 10 percentage points above the value for those born in Spain (Eurostat). For some groups, such as migrants from outside Europe and Latin America, a category which mainly comprises African nationals (in particular Moroccans), unemployment is even higher (Oliver Alonso 2013).

Based on this, as a result of the crisis one would expect a reduction of labour immigration and increased outflows in the form of both return migration and native emigration. The Spanish immigration boom was inextricably linked to the economic bonanza. Up until the 1970s, Spain was mainly a country of emigration, receiving hardly any immigrants (Romero Valiente 2003). As emigration started to dwindle immigration took off, growing exponentially with the arrival of the new century. Until approximately 2009, Spain received an average of almost half a million foreign-born individuals annually, thus becoming the second-largest recipient of immigrants in absolute terms in the OECD after the United States (Arango 2013).

Population censuses show the number of foreign nationals in the country to have risen from some 350,000 in 1981 to close to 5.3 million in 2011. Data from the municipal population registries (Padrón municipal) also show how the number of foreign nationals in Spain increased steadily until 2008, when it reached 5.6 million ( $12 \%$ of the total population). However, by the end of 2014 the foreign population had fallen to 4.7 million. Although this can partly be ascribed to naturalisations, the foreign-born population has also shrunk (from 6.7 million in 2011 to just above 6.1 million) (INE). ${ }^{1}$ Thus, stagnation and decline has been due both to a reduction in immigration and an acceleration of emigration, which has turned the migratory balance negative since 2010. Nevertheless, there is controversy about the significance and characteristics of these new outflows.

\footnotetext{
${ }^{1}$ Provisional data by 1 st January 2015. The Padrón is the most used source in studies of migration in Spain but it has some disadvantages. It can overestimate the number of foreign nationals residing in the country and underestimate emigration flows, since there are no incentives for people to deregister once they leave the country. This could explain the discrepancy between the number of foreign residents estimated by the 2011 Census and those registered by the Padrón in the same year (5.7 million) (OPAM 2013).
} 


\subsection{Recent Emigration: How Many Are Leaving, Where and Who Are They?}

Emigration from Spain has never ceased but it was very much reduced after the 1970s (Valero-Matas et al. 2010). Nevertheless, the number of 'deregistrations'2 (Estadística de Variaciones Residenciales, EVR) from the Padrón from people moving abroad has been increasing steadily over the last decade, with annual figures almost doubling from 2007 to 2014. The external migration statistics (Estadística de Migraciones/Migraciones Exteriores) also show outflows to have risen (see Table 6.2). ${ }^{3}$ In addition, the Padrón for Spanish nationals abroad (PERE) sets the number of this population at almost 2.2 million. This figure does not cover the emigration of foreign nationals from Spain, while it includes people who have acquired Spanish nationality abroad because of their parents or as a result of the Ley de la Memoria Histórica (Law of Historical Memory, which allows descendants of previous emigrants to naturalize) (González Enríquez 2013; Izquierdo and Chao 2014). Of the 174,571 'new registrations' recorded in the PERE by 1st January 2015, almost two-thirds belonged to people born $\mathrm{abroad}^{4}$ (INE).

Based on the above trends, some have argued that the current phenomenon of Spanish emigration abroad is not as preoccupant as portrayed (González Enríquez 2013). Figures suggest that despite the socioeconomic conditions in the country, emigration has not become the main response to the crisis. Given the high unemployment rates and increases in poverty and social exclusion (Llano Ortíz 2015), this could be seen as surprising.

However, there are nuances to this argument. The first is that official numbers could underestimate actual emigration. As already mentioned, there are hardly any incentives for people moving abroad to deregister from the Padrón in Spain, and in the case of Spanish nationals register at consulates. González Enríquez (2014a) argues that following recent reforms, emigrants are even less likely to register abroad and risk losing their right to healthcare in Spain. This seems to be the case especially for EU flows. Following a survey of 2,183 Spanish adults who had emigrated during 2008-2013, Romero Valiente and Hidalgo-Capitán (2014) estimate their rate of under registration in the PERE to be around $50 \%$, climbing to $60 \%$ in the case of intra-EU mobility and $75 \%$ for the United Kingdom. This is why

\footnotetext{
${ }^{2}$ Deregistrations (bajas in Spanish) refer to people who are removed from a particular municipal population registry (Padrón municipal) because they move to another municipality (within Spain or abroad) or for other reasons (death, incorrect registration, expiry date).

${ }^{3}$ Both the EVR and the Estadística de Migraciones use data from the Padrón but while the first simply reports registrations (altas) and deregistrations (bajas), the second employs a more sophisticated methodology to try and be more accurate (it estimates the date of emigration abroad, uses a coefficient of expansion of observed flows, adjusts the information in the Padrón to its own definition of migration, etc.) (INE 2014). As a result, the data from both sources does not necessarily coincide.

${ }^{4}$ These could include nationalized migrants who have returned or re-emigrated as well as those people who have acquired Spanish nationality abroad.
} 


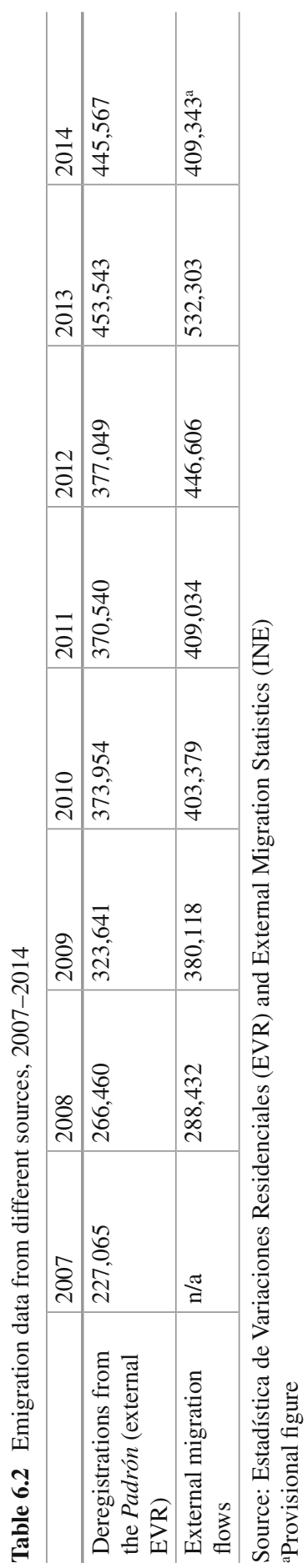


González Ferrer (2013a), using official statistics from countries of origin and main destinations, believes that the number of Spanish emigrants since 2008 could be closer to 700,000. Nevertheless, Romero Valiente and Hidalgo-Capitán (2014) argue that data from destination countries, especially in the EU, could also overestimate the number of Spanish migrants (due mainly to the temporary nature of some migratory movements) (see also Aparicio Gómez 2014).

Secondly, it is important to take into account that emigration is not necessarily available to everyone, and especially to those in the direst of circumstances or with the lowest qualifications. Thus we turn our attention now to who are these new emigrants and where are they going. Despite the shortcomings identified, official statistics can still offer some clues.

According to the PERE, of the just over two million registered Spaniards abroad, almost two-thirds resided in the Americas, mainly in Argentina, followed by Venezuela, Brazil, Cuba, Mexico and the United States. The second largest contingent is in Europe, especially France, Germany, Switzerland and the United Kingdom (INE). These numbers include those who emigrated long ago and their descendants. They reflect the fact that past emigration from Spain was directed mainly towards Latin America, and from the 1960s increasingly to other Western European countries (Romero Valiente 2003; Valero-Matas et al. 2010). These flows were later reversed following first return migration, and later the movement of foreign nationals from Europe (in large part retired people) as well as Latin America and Africa (mainly labour migration) to Spain. Data from the EVR (reflecting deregistrations from the Padrón due to moves abroad ${ }^{5}$ ) as well as new registrations in the PERE, show that recent Spanish emigration has largely followed the same routes (see Table 6.3).

Within Europe, it is recipients of past Spanish emigration, such as Germany, France and Switzerland, as well as the United Kingdom, that register the largest absolute and relative increases in deregistrations from the Padrón. Although there is also a large number of deregistrations linked to Romania, one of the main countries of origin of recent immigration into Spain, in relative terms the increase over the crisis period has been minimal. In Latin America, two of the countries with the highest immigrant presence in Spain, Ecuador and Colombia, have also seen the largest relative increases in people moving there, while figures from Africa and Asia are more modest. Still, the number of deregistrations allocated to Morocco is significant, which could be due largely to return migration.

Data from some of these destinations also suggest that emigration could be higher than what the Spanish statistics reflect, although as mentioned before such figures could be inflated. In the United Kingdom, Spanish applicants for a national insurance number (essential to be able to work) have increased significantly, reaching around 50,000 in 2014 (National Statistics 2015). González-Ferrer (2013a)

\footnotetext{
${ }^{5}$ These figures are just an illustration, since the EVR only has information about country of destination for $26 \%$ of the deregistrations owed to moves abroad. The rest includes cases where the country of destination is not known as well as automatic deregistrations (since 2006 foreign nationals from third countries without permanent residence must renew their registration every 2 years, failing that they are automatically deregistered).
} 
Table 6.3 Deregistrations from the Padrón in Spain as a result of moves abroad and new registrations in the PERE in selected destination countries, 2008-2014

\begin{tabular}{l|c|c|c}
\hline & $\begin{array}{l}\text { Deregistrations in Spain } \\
2008-2014\end{array}$ & $\begin{array}{l}\text { Relative increase } \\
2008 / 2014\end{array}$ & $\begin{array}{l}\text { New PERE } \\
\text { registrations 2014 }\end{array}$ \\
\hline EUROPE & $\mathbf{3 2 0 , 3 7 4}$ & $\mathbf{8 0} \%$ & $\mathbf{5 7 , 2 0 9}$ \\
\hline United Kingdom & 59,425 & $191 \%$ & 12,731 \\
\hline France & 45,977 & $132 \%$ & 13,751 \\
\hline Germany & 45,036 & $163 \%$ & 10,334 \\
\hline Romania & 38,602 & $4 \%$ & 450 \\
\hline Switzerland & 19,187 & $116 \%$ & 5,529 \\
\hline Belgium & 17,837 & $40 \%$ & 4,106 \\
\hline Netherlands & 12,451 & $55 \%$ & 1,728 \\
\hline AMERICAS & $\mathbf{2 3 2 , 2 5 0}$ & $\mathbf{7 8} \%$ & $\mathbf{1 0 7 , 5 9 4}$ \\
\hline Ecuador & 49,852 & $512 \%$ & 10,943 \\
\hline United States & 34,240 & $71 \%$ & 11,626 \\
\hline Argentina & 24,834 & $-11 \%$ & 21,825 \\
\hline Colombia & 24,242 & $196 \%$ & 5,806 \\
\hline Bolivia & 21,815 & $-9 \%$ & 2,387 \\
\hline Venezuela & 19,483 & $52 \%$ & 8,527 \\
\hline Brazil & 17,358 & $0 \%$ & 7,252 \\
\hline AFRICA & $\mathbf{4 1 , 6 4 9}$ & $\mathbf{6 \%}$ & $\mathbf{3 , 3 4 2}$ \\
\hline Morocco & 26,464 & $-1 \%$ & 1,508 \\
\hline ASIA & $\mathbf{2 7 , 9 9 0}$ & $\mathbf{5 6} \%$ & $\mathbf{5 , 2 4 7}$ \\
\hline China & 9,216 & $24 \%$ & 945 \\
\hline Soun: & &
\end{tabular}

Source: Padrón Municipal and PERE (INE)

also shows that non-Germans coming from Spain into Germany increased from some 5,000 in 2008 to 30,000 in 2012. According to official Belgian data, 17,354 Spaniards registered in the country only in the first 4 years of the crisis (DEMO 2013). In the case of flows directed towards Latin America, it is assumed that a large part of these movements are of return migrants (Aparicio Gómez 2014; GonzálezFerrer 2013b).

If recent emigration reflected the groups worst affected by rising unemployment, it would be expected that a large percentage of emigrants would be young, foreign nationals, men and with lower education. However, these are not necessarily the groups with the greater access to moving abroad. Once again, despite its deficiencies, available data provide some evidence. First of all, there seems to be differences between recent emigration to Europe (or the United States) and to Latin America and Morocco. While in the case of the former the latest figures indicate that a majority of emigrants are Spanish nationals born in Spain, in the latter it seems to relate primarily to return migration of nationalized migrants and foreign nationals (see Table 6.4). Spaniards born abroad also represent a significant proportion of those migrating to other European countries, which implies that re-emigration flows are important. Secondly, in absolute numbers, the largest age group in the case of most destinations is the 25-34 years old, with almost equilibrium or a slight majority of men in general. 
Table 6.4 Deregistration from the Padrón in Spain of people moving to main destinations abroad, 2014

\begin{tabular}{l|l|l|l|l|l}
\hline & Men & $\begin{array}{l}\text { Main age } \\
\text { group }\end{array}$ & $\begin{array}{l}\text { Spaniards born } \\
\text { in Spain }\end{array}$ & $\begin{array}{l}\text { Spaniards born } \\
\text { abroad }\end{array}$ & $\begin{array}{l}\text { Foreign } \\
\text { nationals }\end{array}$ \\
\hline Germany & $50.5 \%$ & $25-34$ & $54.2 \%$ & $18.7 \%$ & $27.2 \%$ \\
\hline France & $52.6 \%$ & $25-34$ & $54.2 \%$ & $27.2 \%$ & $18.6 \%$ \\
\hline United Kingdom & $49.5 \%$ & $25-34$ & $46.6 \%$ & $16.7 \%$ & $36.7 \%$ \\
\hline Belgium & $52.0 \%$ & $0-15$ & $47.7 \%$ & $25.9 \%$ & $26.5 \%$ \\
\hline Switzerland & $53.1 \%$ & $25-34$ & $64.6 \%$ & $23.4 \%$ & $12.0 \%$ \\
\hline Morocco & $71.3 \%$ & $25-34$ & $18.0 \%$ & $08.7 \%$ & $73.3 \%$ \\
\hline Argentina & $51.9 \%$ & $25-34$ & $31.5 \%$ & $37.8 \%$ & $30.7 \%$ \\
\hline Bolivia & $50.3 \%$ & $0-15$ & $20.4 \%$ & $29.9 \%$ & $49.8 \%$ \\
\hline Colombia & $50.4 \%$ & $0-15$ & $25.2 \%$ & $42.7 \%$ & $32.1 \%$ \\
\hline Ecuador & $50.3 \%$ & $0-15$ & $33.0 \%$ & $53.0 \%$ & $24.4 \%$ \\
\hline United States & $49.5 \%$ & $25-34$ & $58.1 \%$ & $30.9 \%$ & $11.0 \%$ \\
\hline S & & & &
\end{tabular}

Source: Estadística de Variaciones Residenciales (EVR)

This picture can be contrasted with the few studies conducted on the topic until now. Some suggest that a large proportion of recent emigrants from Spain are foreigners or nationalized migrants, male and up to 45 years in age (González-Ferrer 2013a; González Enríquez 2013; González Enríquez and Martínez Romera 2014). A recent investigation focusing on native Spaniards (born in Spain with both parents born in the country) supports the idea that a majority of recent emigrants are not among the youngest cohorts but closer to the 31-40 age group, with largely a gender balance (Aparicio Gómez 2014). As to their level of education, Spanish emigration towards Europe up to the 1970s was mainly of low skilled workers. However, the outflows that continued after, in great part linked to Spain's entry into the UE, were more selective and composed by and large of highly educated individuals (Alaminos and Santacreu 2010; Alaminos et al. 2010). There are indications that the new emigration since the crisis started includes also mostly qualified people, but these tend to be based on non-representative studies (Aparicio Gómez 2014; González Enríquez and Martínez Romera 2014; Herrera 2014; Izquierdo et al. 2014; Navarrete Moreno 2013). Still, the combination of data from secondary and primary sources has created some public anxiety about the effects of emigration.

\subsection{Policy Responses to Recent Population Movements: The 'Forgotten Emigration'?}

Despite the fact that Spain has a long history of emigration dating back to at least the nineteenth century, is not until the 1950s during the Franco regime and the economic opening of the country that the phenomenon starts to be recognized and promoted as positive. Before, emigration was seen as a negative consequence of the 
failures of society and a personal tragedy (Fernández Asperilla 1998). This change coincides with the processes of industrialisation and urbanisation which created a large labour force that could not always be absorbed, hence the development of population movements inside the country and directed abroad. It was the perceived socioeconomic benefits of this migration abroad that led to a more active promotion and regulation of such flows. Benefits included a reduction in domestic unemployment, social savings as family reintegration was encouraged, and the remittances sent by emigrants.

Thus, from the beginning migration policy in Spain was conceived in utilitarian terms, linked mostly to the needs of the labour market; something that was reproduced when the country became a recipient of immigration. Another main element of migration policy in Spain is its reactiveness (Sánchez Alonso 2011): rather than being the result of reflexion on the long-term consequences, it reacts to what is happening at a precise moment. As a result, authors argue that in general migration flows in Spain have developed outside the legislation (i.e. initially in an 'irregular' manner). The first emigration policies emerged during the Franco period, under the aegis of the Spanish Institute of Emigration (Calvo Salgado et al. 2009), mainly to regulate flows, protect migrants and boost their links with the country in order to maximize benefits for the nation. In this task, authorized private institutions, such as the Catholic Church, played a significant role. The policies in large part consisted of bilateral agreements aimed at exporting labour and regulating workers' rights (Fernández Asperilla 1998).

It was these policies, albeit from a perspective of control and paternalistic assistance, that paved the way for the development later, especially with the restoration of democracy, of other measures such as education programmes, support for migrant associations, the creation of emigrant councils to promote institutional representation or actions directed at elderly migrants as well as the second and subsequent generations (Calvo Salgado et al. 2009). After the 1978 Constitution, emigrants became first class citizens with the same rights as other Spaniards, including the right to vote. At the regional level, the new autonomous communities in Spain also created their own plans to encourage and aid return migration. However, although emigration (and return to Spain) continued to be a political and public issue, as outflows declined some of its relevance was lost and no major legislative advancements were made for the next years. The lack of attention to emigration and emigrants persisted and became more blatant as the focus turned towards immigration flows. This led some experts to use the term "the forgotten emigration" when referring to the large population of Spaniards still residing abroad (Reques Velasco and de Cos Guerra 2003).

It is not until 2004-2008, under the Socialist Zapatero government, that new legislation is introduced. These laws responded partly to ideological interests and affected the descendants of previous migrants (Alemán and Alonso 2012). ${ }^{6}$ One

\footnotetext{
${ }^{6}$ Law 3/2005 offered economic benefits to Spanish citizens who left the country as a consequence of the Civil War (1936-1939), while Law 52/2007 (Law for Historical Memory) among other things allowed former Spanish nationals and their descendants abroad to recover their Spanish
} 
immediate consequence was the enlargement of the registered Spanish population abroad, as mentioned previously. However, the legislation also provided for the further regulation of the social, educational, cultural and participation rights of Spanish emigrants (Merino Hernando 2012). Mechanisms were designed to promote the creation of associations abroad and specific budget plans were dedicated to the descendants of Spanish emigrants, to reinforce their education, training and cultural links with Spain. This way the central government, with the support of regional administrations, after years of certain abandonment (except during electoral periods) tried to strengthen connections with Spaniards abroad as active citizens and potential voters.

The arrival of the crisis in 2008 and the inauguration of a conservative government in 2011 opened up a new period in migration policy. Initially, policies focused on the return of immigrants; following the utilitarian conceptions of the past, the idea was that if there was not enough work in Spain migrants should leave (thus reducing unemployment and social problems). Voluntary return plans had existed since 2003, both for humanitarian and other reasons. However, in 2008 the Socialist government implemented a new plan for jobless migrants to receive part of their accumulated unemployment benefit in their home countries, with the condition that they would not come back to Spain in at least 3 years. Although there is little information on the success of such plans, studies suggest that it has been rather modest, with return remaining a minority decision and in most cases undertaken outside institutionalized channels (Parella and Petroff 2014). Still, such outflows have served to cast recent emigration as a matter of mostly return migration, thus minimizing the phenomenon of the 'expulsion' of native Spaniards (or that of naturalized migrants, as well as second generation migrants born in the country) by the crisis and its potential consequences.

At the same time, the spending cuts and policies put in place by the ruling Partido Popular (PP conservative party) to respond to the crisis and reduce immigration (especially that of an 'irregular' nature) have affected Spaniards abroad, for instance through the closing down of consulates (Romero Valiente and Hidalgo-Capitán 2014). Another example are the new regulations introduced in 2012 to stop migrants in an irregular situation from receiving free healthcare that also limit access to health services in Spain to nationals residing outside the country. ${ }^{7}$ Equally, the electoral reforms of 2011 introduced the need for Spaniards abroad to actively express their desire to vote in order to be able to participate in national and regional elections in the home country (before, ballots were sent to them automatically). The result has been a massive reduction in participation (to $5 \%$ in the 2011 general elec-

nationality. Law 40/2006 (Statute for Spanish Citizens Abroad) was promulgated to boost the rights of emigrants.

${ }^{7}$ González Enríquez (2014a, b) explains that new regulations mean that Spaniards residing abroad for over 3 months lose their right to free healthcare in Spain; this could mean that less of them will register as permanent residents in the consulates. These new regulations were partly reversed in 2015, when the central government announced that it would reinstate the right to primary healthcare to all immigrants (El País 2015). 
tion, compared with $31 \%$ in 2008) (Ramírez 2015; Ruiz González 2014). These and other related issues have generated controversy in the wider political and public context as discussed next.

\subsection{The Wider Political and Public Debates: Ideological Differences and Biases}

Recent emigration from Spain started to become a political issue from 2011, following the change of government and publication of data indicating that the country was losing population (Nogueira 2011). Nevertheless, by and large the political debate has been low key and played along ideological lines. The right-wing government hardly refers to the phenomenon and when it does it describes outflows mainly as the result of return migration or of globalisation and mobility within Europe. Also, the authorities have made emphasis on the high skill levels of young Spaniards and their desire for adventure (ABC.es 2012). This discourse has been contested by the Socialist opposition (PSOE), who blames the PP for lack of opportunities in the country and alert about brain drain and loss of human capital (Quesada 2015). The left-wing parties also talk about "economic exile" and "economic migrants expulsed from Spain", with Podemos seeking to court the support of Spaniards abroad (Gómez 2014). The latest party that has emerged with force, the centre-right Ciudadanos, on the other hand, has not made many pronouncements on this topic. ${ }^{8}$

With regard to the attention paid by the main political groups to emigrants abroad, the traditional parties, PP and PSOE, have a network of supporters and institutions dedicated to them that tends to be activated at election time. ${ }^{9}$ Recently, both have made attempts at attracting the support of new emigrants. The PP, for instance, has promoted the idea of a "certificate" for emigrants returning to Spain to help with their social, health and labour reintegration. The PSOE, on the other hand, has asked for increased spending on social and other services for emigrants and the elimination of the new restrictions on voting from abroad, as well as proposing the creation of a plan for the return of high skilled emigrants. Newer parties such as Podemos include some proposals in its electoral programme, including the creation of a census of emigrants, social aid for those expulsed by the crisis and in need and mechanisms to make sure that those working in other EU countries do not lose their social security rights; while Ciudadanos hardly makes any references to Spaniards abroad in its website. ${ }^{10}$

\footnotetext{
${ }^{8}$ This party is more known for its hostile position on immigration than for its views on current emigration (El Mundo 2015).

${ }^{9}$ See information in the parties' websites: "PSOE en el Mundo" (PSOE in the World) http://web. psoe.es/ambito/mundo/news/index.do (Accessed 14 October 2015); PP "En el exterior"(PP abroad) http://www.pp.es/conocenos/en-el-exterior (Accessed 14 October 2015).

${ }^{10}$ Information obtained from parties' websites and newspapers. PP (http://www.pp.es/), PSOE (http://www.psoe.es/ambito/actualidad/home.do), Podemos (http://podemos.info/), Ciudadanos
} 
By contrast, the space that the new outflows have occupied in the wider public debates is more significant and varied. In the media, what is referred to as the "new" or "second" emigration has been quite visible. A brief overview of news on "emigration" published since 2011 by the two main newspapers in readership, El País (closer to PSOE) and El Mundo (more conservative), shows both have written numerous articles. The emphasis is on how the crisis is affecting highly educated young people as well as fostering return migration. El País has run a series covering the main destinations of recent outflows, people's reasons for leaving, difficulties encountered and family consequences. These stories talk about people been forced to emigrate because of the socioeconomic context and government policies (for example, cuts in research and university spending leading academics to emigrate). This raises questions about brain drain. El Mundo, on the other hand, also presents stories of successful business people and entrepreneurs that have emigrated. Both newspapers reported how in 2013 after 10 years Spain became a net receiver of migrant remittances again. In addition, there has been increasing concern about Spain's shrinking and ageing population, as immigration falls and emigration increases. The media has also echoed political and academic disputes about the nature of recent emigration, and flagged the issue of the external vote in the run-up to elections (Garea 2015).

Internet and the social media, on the other hand, have helped present more alternative or public views on the subject, and as a medium for emigrants to have their saying. For instance, an emotive video of two young emigrants returning home to see their families served to denounce the economic and political situation in Spain as a cause of emigration and became an instant success (González 2013). ${ }^{11}$ Several online platforms have also emerged to defend the views and rights of those who have left, such as Marea Granate (Maroon Tide), ${ }^{12}$ which describes itself as "a transnational movement formed by emigrants of the Spanish state and supporters, whose objective is to fight against the causes and those who have provoked the economic and social crisis that forces us to migrate" (see Chap. 7). Other similar alternatives include the campaign No nos vamos, nos echan (We don't leave, they throw us out), organized by the group Juventud Sin Futuro (Youth Without a Future), or Yo también soy una leyenda urbana (I am also an urban myth), launched by AACTE (Asociación para el Avance de la Ciencia y la Tecnología en España, Association for the Advancement of Science and Technology in Spain), created to protest against government comments saying that brain drain in Spain was an urban myth (Ansede 2014). ${ }^{13}$

\footnotetext{
(https://www.ciudadanos-cs.org/).

${ }^{11}$ The video is called LA SORPRESA: dedicado a todos los que están lejos, and was made by two young emigrants, Jorge and Esther. https://www.youtube.com/watch?v=qxu5W4bj4I8 (Accessed 15 February 2015).

${ }^{12}$ This refers to the colour of Spanish passports.

${ }^{13}$ Information obtained from their websites: http://mareagranate.org/, http://juventudsinfuturo.net/ and http://www.aacte.eu/wp/blog/2014/12/08/leyendas-urbanas/ (Accessed 15 February 2015).
} 
Finally, most of the public representations and discourses, including that of emigrants themselves, tend to offer an image of emigration as conformed only by young people and professionals. The emigration of the less skilled, poorer, older people and families remains almost invisible, referred to only as a thing of the past, somehow in contraposition to what is supposed to be happening now. Little is being said as well about issues such as the fact that many migrants abroad, despite their qualifications, are working below their skill levels and accessing the most precarious jobs, or about nationalized migrants re-emigrating (Domingo and Sabater 2013; Torres Pérez 2014). However, there is evidence that emigration in Spain is touching different sectors of society and is not as rosy a picture as some would like to paint.

\subsection{Conclusions}

The economic crisis has had a clear demographic impact in Spain. Following its emigration history, since the mid-1970s the country had enjoyed a positive migratory balance, with the number of people arriving increasingly superior to those leaving. These population movements were strongly linked to developments in the labour market, among other factors. Nevertheless, Spain is one of the European countries worst affected by the economic and financial crisis that erupted at the end of 2007. Although the impact on migration flows was not immediate, by 2010 the migratory balance had turned negative once again, as a result of both reduced immigration and increased emigration. Outflows have not reached the dimensions of the past, although official figures fail to reflect their real size. We know little about their characteristics as well, apart from the fact that they seem directed mainly towards Europe (in the case of native Spaniards) and the Americas (mostly return migration), and are partly composed of young, high skilled migrants. This generates concerns about the lack of work and opportunities in Spain, brain drain and human capital losses, and population ageing.

Despite such preoccupations, the political and policy responses have been quite subdued. Hardly any measures have been taken to know more about recent outflows or help new emigrants. Emigration policies have been almost absent from the Spanish panorama for decades, while measures implemented recently on healthcare or voting have actually proven detrimental to nationals abroad. Although the wider public debate has been more prolific, by and large it has followed ideological lines (for or against the government), as well as giving voice to some emigrants. In general, less skilled, poorer emigrants, as well as those returning or re-emigrating, remain absent from public debates. Partly, this is because the government presents recent emigration as mostly the result of labour globalisation and young people widening their experiences, while its emphasis is on demonstrating that the crisis is over. An example of this is a recent document of the think tank Real Instituto Elcano analysing Spain's strategic priorities on international migration, where out of six main points only one refers to emigration. This point describes recent outflows as "an opportunity to extend the presence of our country abroad, to create business and 
commercial networks and to spread the Spanish culture", and calls for the need to facilitate further external mobility (González Enríquez 2014b: 7). No reference is made to the causes of recent emigration or the social and personal consequences, especially for the most vulnerable emigrants. Clearly, more in-depth research and analysis of recent emigration flows from Spain is needed in order to detect the consequences and implement the right policies.

\section{References}

ABC.es. (2012, December 1). Marina del Corral achaca la emigración de jóvenes españoles "al impulso aventurero". ABC.ES. http://www.abc.es/economia/20121201/abci-emigracionjovenes-aventureros-marina-201212011242.html. Accessed 14 Feb 2015.

Alaminos, A., \& Santacreu, O. (2010). La emigración cualificada española en Francia y Alemania. Papers, 95(1), 201-211.

Alaminos, A., Albert, M. C., \& Santacreu, O. (2010). La movilidad social de los emigrantes españoles en Europa. Revista Española de Investigaciones Sociológicas, 129, 13-35.

Alemán Bracho, C., \& Alonso Seco, J. M. (2012). Políticas públicas para inmigrantes y emigrantes en España. Aproximación histórica, teórica y legislativa. Azarbe, Revista Internacional de Trabajo Social y Bienestar, 1, 7-19.

Alonso Pérez, M., \& Furio Blasco, E. (2010). La economía española. Del crecimiento a la crisis pasando por la burbuja inmobiliaria. Cahiers de civilisation espagnole contemporaine. De 1808 au temps présent, 6. Electronic ISSN 1957-7761.

Ansede, M. (2014, December 16). Los científicos exiliados claman que no son "una leyenda urbana". El País. http://elpais.com/elpais/2014/12/16/ciencia/1418757917_801968.html. Accessed 15 Feb 2015.

Aparicio Gómez, R. (2014). Aproximación a la situación de los españoles emigrados: realidad, proyecto, dificultades y retos. Madrid: OIM.

Arango, J. (2013). Exceptional in Europe? Spain's experience with immigration and integration. Washington, DC: Migration Policy Institute.

Calvo Salgado, L. M., Fernádez Vicente, M. J., Kreienbrink, A., Sanz Díaz, C., \& Sanz Lafuente, G. (2009). Historia del Instituto Español de Emigración. Madrid: Ministerio de Trabajo e Inmigración.

DEMO \& Centre pour l'égalité des chances et la lutte contre le racisme. (2013). Migrations et populations issues de l'immigration en Belgique. Rapport statistique et démographique 2013. Louvain-la-Neuve: Centre de recherche en démographie et sociétés (DEMO), Université Catholique de Louvain. Brussels: Centre pour l'égalité des chances et la lutte contre le racisme.

Domingo, A., \& Sabater, A. (2013). Emigración marroquí desde España en contexto de crisis. Riem (Revista Internacional de Estudios Migratorios), 31(1), 29-60.

El Mundo. (2015, April 7). Ciudadanos apoya conceder la tarjeta sanitaria sólo a españoles y a inmigrantes con papeles. http://www.elmundo.es/espana/2015/04/07/5523a3b9e2704e4e558b 457a.html. Accessed 14 Oct 2015.

El País. (2015, March 3). Alonso anuncia que devolverá la atención primaria a los sin papeles. http://politica.elpais.com/politica/2015/03/31/actualidad/1427788718_943883.html. Accessed 13 Oct 2015.

Fernández Asperilla, A. (1998). La emigración como exportación de mano de obra: el fenómeno migratorio a Europa durante el franquismo. Historia Social, 30, 63-81. 
Garea, F. (2015, October 13). El PP se niega a eliminar las trabas al voto en el exterior. El País. http://politica.elpais.com/politica/2015/10/12/actualidad/1444668947_019129.html. Accessed 14 Oct 2015.

Gómez, L. (2014, September 15). Podemos lleva a Londres su mensaje a los 'emigrantes económicos expulsados de España'. El Mundo. http://www.elmundo.es/espana/2014/09/13/5414664de 2704e1f398b4580.html. Accessed 14 Feb 2015.

González, L. (2013, October 8). La Sorpresa: vídeo emotivo sobre emigrados que vuelven a su casa por sorpresa. El Huffington Post. http://www.huffingtonpost.es/2013/10/08/la-sorpresavideo-abrazos_n_4061923.html. Accessed 15 Feb 2015.

González Enríquez, C. (2013). ¿Emigran los españoles?. ARI, 39/2013. Madrid: Real Instituto Elcano.

González Enríquez, C. (2014a, May 6). Cuántos vienes y cuántos se van: El acceso a la sanidad y la oscuridad estadística sobre migraciones. Comentario Elcano, 42/2014. Madrid: Real Instituto Elcano.

González Enríquez, C. (2014b, July 17). Prioridades estratégicas de la acción exterior española en relación con las migraciones. Madrid: Real Instituto Elcano.

González Enríquez, C., \& Martínez Romera, J. P. (2014). Country focus: Migration of Spanish nationals during the crisis. Madrid: Real Instituto Elcano.

González-Ferrer, A. (2013a). La nueva emigración española. Lo que sabemos y lo que no. Zoom Político, 2013/18. Madrid: Laboratorio de Alternativas.

González-Ferrer, A. (2013b). Retorno y reintegración de los migrantes latinoamericanos en Europa. In FIIAPP (Ed.), Propuestas para vincular las políticas de migración y empleo (pp. 53-89). Madrid: FIIAPP.

Herrera, M. J. (2014). Migración cualificada de profesionales de España en el extranjero. In J. Arango, D. Moya Malapeira, \& J. Oliver Alonso (Eds.), Inmigración y emigración: mitos y realidades. Anuario de la Inmigración en España 2013 (pp. 91-107). Barcelona: CIDOB.

INE (2014). Estadística de Migraciones. Metodología. Instituto Nacional de Estadística (INE). http://www.ine.es/metodologia/t20/t2030277.pdf. Accessed 01 Mar 2016.

Izquierdo, A., \& Chao, L. (2014). Ciudadanos españoles producto de la Ley de la Memoria Histórica: motivos y movilidades. In P. Mateos (Ed.), Ciudadanía Múltiple y Migración: Una Perspectiva Latinoamericana (pp. 141-178). México DF: CIDE - CIESAS.

Izquierdo, M., Jimeno, J. F., \& Lacuesta, A. (2014). La emigración de españoles durante la Gran Recesión (2008-2013). Cuadernos Económicos de ICE, 87, 223-240.

Llano Ortíz, J. C. (2015). El estado de la pobreza $4^{\circ}$ Informe. Resumen ejecutivo. Seguimiento del indicador del riesgo de pobreza y exclusión social en España 2009-2013. EAPN-España. http:// www.eapn.es/ARCHIVO/documentos/noticias/1423562383_20150121_el_estado_de_la_ pobreza._seguimiento_del_arope_2013_resumenejecutivo.pdf. Accessed 10 Feb 2015.

Merino Hernando, M. A. (2012). Del "retorno del emigrante" a "la bienvenida del ciudadano en el exterior": los giros de la política española en el nuevo contexto migratorio entre España y Argentina. Stvdia Zamorensia, 11, 45-64.

National Statistics. (2015, February 26). National Insurance Number Allocations to Adult Overseas Nationals Entering the UK - registrations to December 2014. Statistical Bulletin. https://www. gov.uk/government/uploads/system/uploads/attachment_data/file/407501/NINo_Analytical_ Report_Feb15.pdf. Accessed 9 Oct 2015.

Navarrete Moreno, L. (coord.) (2013). La emigración de los jóvenes españoles en el contexto de la crisis. Análisis y datos de un fenómeno difícil de cuantificar. Madrid: Observatorio de la Juventud en España.

Nogueira (2011, July 25). España pierde población. El País. http://elpais.com/diario/2011/07/25/ sociedad/1311544803_850215.html. Accessed 14 Oct 2015.

Oliver Alonso, J. (2013). La inmigración y la doble recesión del mercado de trabajo en España 2011-12. In E. Aja, J. Arango, \& J. Oliver Alonso (Eds.), Inmigración y crisis: entre la continuidad y el cambio. Anuario de Inmigración en España (edición 2012) (pp. 28-58). Barcelona: CIDOB. 
OPAM. (2012). El impacto de la crisis económica en la situación laboral de los jóvenes inmigrantes. Tema OPAM, 7 (diciembre). Sevilla: Observatorio Permanente Andaluz de las Migraciones.

OPAM. (2013). España, ¿país de emigración? La imagen de éxodo a prueba de evidencia estadística. Tema OPAM, 8 (junio). Sevilla: Observatorio Permanente Andaluz de las Migraciones.

Ortega, E., \& Peñalosa, J. (2012). Claves de la crisis económica española y retos para crecer en la UEM. Documentos Ocasionales, 1201. Madrid: Banco de España.

Parella, S., \& Petroff, A. (2014). Migración de retorno en España: salidas de inmigrantes y programas de retorno en un contexto de crisis. In J. Arango, D. Moya Malapeira, \& J. Oliver Alonso (Eds.), Inmigración y emigración: mitos y realidades. Anuario de la Inmigración en España 2013 (pp. 62-87). Barcelona: CIDOB.

Quesada, J.D. (2015, August 30). Pedro Sánchez avanza un plan para recuperar el talento emigrado. El País. http://internacional.elpais.com/internacional/2015/08/29/actualidad/1440870356_439294.html. Accessed 14 Oct 2015.

Ramírez, P. (2015, February 3). Emigrantes españoles sin voto. El Mundo. http://www.elmundo.es/ espana/2015/02/03/54cfd8a8e2704ed42d8b4583.html. Accessed 13 Feb 2015.

Reques Velasco, P., \& de Cos Guerra, O. (2003). La emigración olvidada: la diáspora española en la actualidad. Papeles de Geografía, 37, 199-216.

Romero Valiente, J. M. (2003). Migraciones. In A. Arroyo Pérez (Ed.), Tendencias demográficas durante el siglo XX en España (pp. 207-253). Madrid: Instituto Nacional de Estadística.

Romero Valiente, J. M., \& Hidalgo-Capitán, A. L. (2014). El subregistro consular: magnitudes y efectos en las estadísticas de emigración españolas. OBETS. Revista de Ciencias Sociales, 9(2), 377-407.

Ruiz González, J. G. (2014). El voto exterior en España. Reflexiones tras la reforma. Más Poder Local, 19, 10-11.

Sánchez Alonso, B. (2011). La política migratoria en España.Un análisis de largo plazo. Revista Internacional de Sociología (RIS), 1, 243-268.

Torres Pérez, F. (2014). Crisis y estrategias de los inmigrantes en España: el acento latino. Revista CIDOB d'Afers internacionals, 106-107, 215-236.

Valero-Matas, J. A., Coca, J. R., \& Miranda-Castañeda, S. (2010). The migratory flows in Spain: An analysis of the migration and immigration input from European Union. Papeles de Población, 16(65), 233-256.

Open Access This chapter is licensed under the terms of the Creative Commons AttributionNonCommercial 2.5 License (http://creativecommons.org/licenses/by-nc/2.5/), which permits any noncommercial use, sharing, adaptation, distribution and reproduction in any medium or format, as long as you give appropriate credit to the original author(s) and the source, provide a link to the Creative Commons license and indicate if changes were made.

The images or other third party material in this chapter are included in the chapter's Creative Commons license, unless indicated otherwise in a credit line to the material. If material is not included in the chapter's Creative Commons license and your intended use is not permitted by statutory regulation or exceeds the permitted use, you will need to obtain permission directly from the copyright holder.

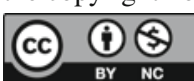

